\title{
O Brasil e a segurança alimentar
}

\section{Brazil and food security}

Passaram-se quatro anos desde a implantação formal do Programa de Segurança Alimentar, proposto como carro chefe da política social do Governo do Presidente Luiz Inácio Lula da Silva. Também conhecido, em sua versão popular, como o Programa Fome Zero, a iniciativa governamental corporifica um conjunto de ações estratégicas, mobilizando compromissos de várias agências públicas e privadas, tendo como propósito convergente alcançar uma situação em que todas as pessoas, em todos os espaços geográficos, durante todo o tempo, tenham pleno acesso a uma cesta básica de alimento capaz de assegurar a cobertura total de suas necessidades orgânicas de energia e nutrientes, segundo as recomendações dos comitês internacionais credenciados pelas Nações Unidas para tratar do assunto. Mais alguns adendos: o atendimento destas necessidades deve respeitar os hábitos alimentares das diferentes populações (evidentemente, desde que corretos), mediante produtos de boa qualidade, sem prejuízo do cumprimento de outros direitos básicos: de saúde, de educação, de moradia, de participação, fundamentalmente assegurados pelo exercício de uma atividade econômica ética e socialmente aceita, de forma a respeitar a auto-estima do indivíduo e sua comunidade. Por fim, a segurança alimentar, que se concretiza, em termos de saúde, com o bem estar nutricional, deve ser um processo auto-sustentável, respeitando os ecossistemas físicos e bióticos: o solo, as águas, o ar, a flora e a fauna, segundo os princípios de uma saudável biodiversidade, que o "progresso", sob a égide de objetivos dominante ou exclusivamente econômicos, passou a comprometer e até a subverter.

Portanto, mais do que um programa de governo, auto-limitado nas responsabilidades de um mandato eletivo, o conceito ampliado de segurança alimentar e nutricional configura um ideal de cidadania, tendo como ponto de partida as necessidades materiais mais elementares do homem: a alimentação sadia, completa, equilibrada e adequada. Não é uma proposta para um quadriênio apenas. No entanto, não se trata de um compromisso limitado às contingências temporais, políticas e institucionais de um governo, mas de um projeto que demanda a força de vontade e a mobilização de toda uma geração. O retrospecto dos últimos quatro anos possibilita já uma experiência razoável para se avaliar o saldo do processo percorrido e as perspectivas dos desafios a serem enfrentados.

O Brasil tem, atualmente, uma produção anual de 120 milhões de toneladas de grãos. Somos auto-suficientes e até grandes exportadores de carne de gado e de aves. Contamos com uma disponibilidade de 3000 calorias e de 100 gramas diárias de proteínas por habitante, mais da metade oriundas de alimentos de origem animal. Seguramente, em nível de mercado interno, dispõe-se de um excedente de $40 \%$ de oferta calórica e de $50 \%$ no que se refere às necessidades efetivas de proteínas. Nesses dois aspectos, poucos países têm uma situação tão confortável. Ademais, temos a fronteira agropecuária que mais cresce no mundo - os extensos campos do centro-oeste brasileiro, com indicadores que rivalizam com o milagre econômico da Índia e da China, atingindo índices anuais de incremento de 7\% a 10\%. Afora os abusos de uma exploração predatória, dispomos de imensas possibilidades de diversificar e expandir nossa pauta de produção alimentar, desde que dispomos de quase $20 \%$ de todas as terras agricultáveis do mundo, para uma população que representa apenas 3\% do efetivo demográfico do planeta. Com uma variedade de climas e de solos que possibilita uma diversificação incomparável de modelos e sistemas produtivos, o Brasil, mais do que o presente, tem pela frente um horizonte seguramente promissor.

Portanto, nossas limitações já não se encontram no que produzimos ou que poderemos produzir, em termos de alimentos básicos. O ponto de passagem crucial na cadeia alimentar/nutricional do Brasil está no elo do consumo, afetado, de um lado, pelas restrições do poder de compra da população e, por outra parte, pela pressão das demandas induzidas pelo mercado. Os fast-foods, os snakes, as guloseimas, os refrigerantes, as pitadas de sal e de açúcar modificando as propriedades organolípticas dos substratos alimentares, os modismos criados pela indústria e pelo comércio com o suporte da mídia, criaram novos perfis de consumo, em sua maior parte em desacordo com os hábitos de uma alimentação saudável.

Sem dúvidas, as adversidades socioeconômicas herdadas do passado, gerando e mantendo um contexto de desigualdades, rivalizam com os desvios do mercado globalizado e "vídeo-dependente" do presente. É perti- 
nente observar que, se não figuramos entre os países mais pobres do mundo (ao contrário, estamos no ranking dos dez maiores PIBs nacionais), fazemos parte do bloco das cinco nações mais desiguais no que concerne à distribuição de riquezas. Assim, 42 milhões de brasileiros representam a população submersa sob a linha de pobreza, metade sub-classificada na categoria da indigência, também chamada de pobreza absoluta. São pessoas e famílias potencialmente expostas à insegurança alimentar. Mesmo considerando que, nos últimos quatro anos, três milhões de patrícios conseguiram emergir desse patamar socialmente crítico, ainda assim estamos com um contingente de pobres que compromete, frontalmente, os ideais de democracia e de cidadania.

O programa "Bolsa Família" já cobre, teoricamente, os 42 milhões de pobres, transferindo, em média, 20\% do valor monetário do salário mínimo para dez milhões de famílias. Por outra parte, 37 milhões de escolares tiveram o valor per capita de suas dotações orçamentárias duplicados para a compra de alimentos da chamada "merenda escolar". Oito milhões de empregados de empresas são beneficiários do Programa de Alimentação dos Trabalhadores (PAT). A agricultura familiar conta atualmente com 7,5 bilhões de reais em crédito, contra apenas dois bilhões, há quatro anos. Com diferentes públicos-alvo, o programa de cestas alimentares é um dispositivo de apoio emergencial para situações transitórias ou permanentes de crise alimentar mais ostensiva (deslocados das secas ou das áreas de inundação, quilombolas, catadores de lixo, recém-assentados da reforma agrária, etc). Trata-se de um grande avanço, mas, ao mesmo tempo, uma evidência de desconforto político e social, na medida em que expressa o enorme contingente de famílias e pessoas não incluídas no processo de produção e distribuição social de bens e serviços, ou seja, não inseridas no corpo estrutural do desenvolvimento. Afinal de contas, são quase dez milhões de desempregados ou sub-empregados, apesar dos seis milhões de ocupações formais, com carteiras assinadas, produzidas nesse período.

\section{Malaquias Batista Filho}

Conselho Nacional de Segurança Alimentar. Membro do Conselho Editorial da Revista Brasileira de Saúde Materno Infantil. 